\title{
Monsoon response to changes in Earth's orbital parameters: comparisons between simulations of the Eemian and of the Holocene
}

\author{
P. Braconnot ${ }^{1}$, C. Marzin ${ }^{1}$, L. Grégoire ${ }^{2}$, E. Mosquet ${ }^{1}$, and O. Marti ${ }^{1}$ \\ ${ }^{1}$ Laboratoire des Sciences du Climat et de l'Environnement, Unité mixte CEA-CNRS-UVSQ, Orme des Merisiers, bât. 712, \\ 91191 Gif-sur-Yvette Cedex, France \\ ${ }^{2}$ School of Geographical Sciences, University of Bristol, University Road, Bristol, BS8 1SS, UK
}

Received: 1 February 2008 - Published in Clim. Past Discuss.: 21 April 2008

Revised: 22 September 2008 - Accepted: 7 October 2008 - Published: 24 November 2008

\begin{abstract}
Monsoon is the major manifestation of the seasonal cycle in the tropical regions, and there is a wide range of evidence from marine and terrestrial data that monsoon characteristics are affected by changes in the Earth's orbital parameters. We consider 3 periods in the Eemian and 3 in the Holocene that present some analogy in the Earth's orbital configuration in terms of obliquity and precession. Simulations with the IPSL_CM4 ocean-atmosphere coupled model allow us to discuss the response of the Indian and African monsoon in terms of amplitude and response to the insolation forcing. Results show that precession plays a large role in shaping the seasonal timing of the monsoon system. Differences are found in the response of the two sub-systems. They result from the phase relationship between the insolation forcing and the seasonal characteristics of each subsystem. Also the response of the Indian Ocean is very different in terms of temperature and salinity when the change in insolation occurs at the summer solstice or later in the year. Monsoon has a large contribution to heat and water transports. It is shown that the relative importance of monsoon on the change in the energetic of the tropical regions also vary with precession.
\end{abstract}

\section{Introduction}

Since the 80 's, changes in the Earths orbital parameters have been recognized as the pacemaker of the climate system (i.e. Berger, 1988). There is now a wide range of evidences from

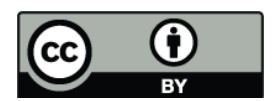

Correspondence to: P. Braconnot (pascale.braconnot@cea.fr) different environmental indicators over land, ice and ocean that the Asian monsoon varies depending on the insolation forcing (Wang et al., 2005). Several modeling studies have tested the impact of insolation on the response of monsoon. For example Prell and Kutzbach (1987) clearly establish a quasi-linear relation between monsoon precipitation in West Africa and in India and the summer insolation integrated over the Northern Hemisphere (NH). Several feedbacks have also been identified to trigger the response of the system to the initial insolation signal, such as the response of the ocean and of the vegetation (Braconnot, 2004; Braconnot et al., 2004; Cane et al., 2006).

In most studies the monsoon has been considered as one phenomenon affecting a tropical belt from Africa, India to South East and East Asia. Little attention has been put on possible differences in the response of the different monsoon sub-systems to the changes in the intensity and in the seasonal timing of the insolation forcing. However regional dissimilarities have been identified when comparing the role of the ocean feedback on the African and the Indian monsoons. Braconnot et al. (2007b) for example have shown from the most recent set of coupled simulations of the midHolocene that the feedbacks from the ocean tend to amplify the strengthening of the African monsoon induced by insolation, whereas in India they tend to reduce it. The reason is that an interhemispheric gradient is created in the Atlantic Ocean, which favors the inland advection of moist air into the continent (Kutzbach and Liu, 1997; Braconnot et al., 2000; Zhao et al., 2005). In the Indian and Asian sector, on the contrary, the ocean surface warming during summer, favors the development of deep convection over the ocean at the expense of the continent (Liu et al., 2004; Braconnot et al., 2007b).

Published by Copernicus Publications on behalf of the European Geosciences Union. 
Table 1. Orbital characteristics for the 6 simulations considered in this study.

\begin{tabular}{rccccc}
\hline Period & Eccentricity $\left({ }^{\circ}\right)$ & Obliquity $\left({ }^{\circ}\right)$ & Precession $\left(\omega-180^{\circ}\right)$ & \multicolumn{2}{c}{ Length of the seasons } \\
& & & & VE to AE (days) & AE to VE (days) \\
\hline $126 \mathrm{ka}$ & 0.0397 & 23.9 & 201 & 192 & 168 \\
$122 \mathrm{ka}$ & 0.0407 & 23.2 & 356 & 186 & 174 \\
$115 \mathrm{ka}$ & 0.0414 & 22.4 & 111 & 175 & 185 \\
$9.5 \mathrm{ka}$ & 0.0194 & 24.2 & 303 & 188 & 172 \\
$6 \mathrm{ka}$ & 0.0187 & 24.1 & 1 & 184 & 180 \\
$0 \mathrm{ka}(\mathrm{ctrl})$ & 0.0167 & 23.4 & 102 & 180 & 180 \\
\hline
\end{tabular}

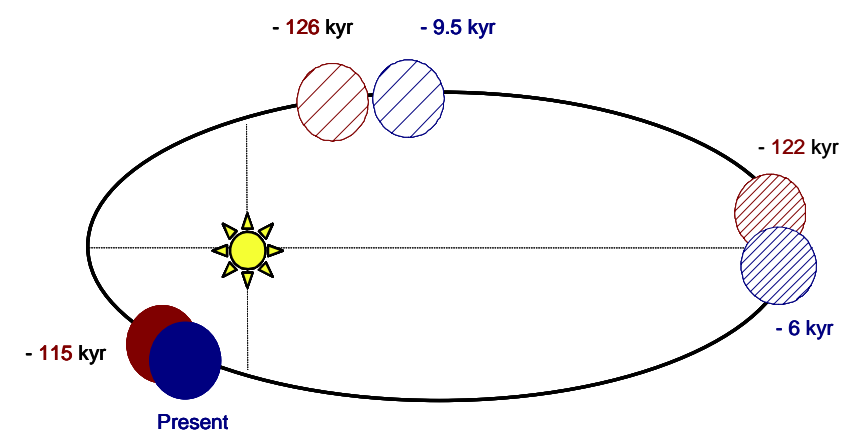

Fig. 1. Location of the vernal equinox on the Earth's orbit around the Sun for the 6 simulations considered in this study.

Other effects need to be accounted for when analyzing the response of monsoons to the insolation forcing. Precession plays a large role in modulating the length of the season. Braconnot and Marti (2003) have shown that the response of the Indian ocean is very different whether the change in insolation occurs in early or late summer. In the first case the mixed layer depth in the Indian Ocean is shallower than in the control simulation and the ocean responds in phase with the insolation forcing. In the second case, the mixed layer depth remains deeper during a large part of the year and the ocean responds with a larger delay (one to two months) to the insolation forcing. The changes in the mixed layer depth are a function of the winter mixing and of the change in local precipitation and river runoff that favor the development of the halocline in the Indian Ocean.

The change in the timing of the insolation forcing relative to the equinoxes and solstices also has implications on the development and the response of the different monsoon subsystems. Prell and Kutzbach (1987) found different regression parameters between insolation and precipitation for India and Africa. Furthermore Marzin and Braconnot (in revision, 2008) report that the decrease of the African monsoon between the Early Holocene and the mid-Holocene was relatively smaller than for the Indian monsoon. They argued that the reason is a resonant response of the Indian monsoon to the insolation forcing when the maximum change in in- solation occurs near the summer solstice and a resonant response of the African monsoon when the maximum insolation change is delayed after the summer solstice.

In this manuscript we investigate this effect using a large set of simulations covering different periods in the Holocene and the last interglacial period (Eemian, LIG) that present analogies in the orbital configurations. Earth's orbital parameters were chosen in order to represent different seasonal timing compared to the modern insolation. Since the effect of precession is larger when the eccentricity is large, we also expect to have a larger impact of the seasonal shift in the simulations of the LIG. We investigate the response of the monsoon system and the amplification of the African and Indian monsoon. We also consider how the changes in the seasonal cycle affect the characteristics of the upper ocean in the Indian Ocean, by analyzing the changes in temperature and salinity and the link with the seasonal evolution of the mixed layer depth.

Monsoon is also part of the global energetics and participates to the redistribution of heat and water across the two hemispheres and between land and ocean. Braconnot et al. (2000) reported that for the mid-Holocene the role of the ocean in redistributing heat is equivalent between ocean and atmosphere in the tropical regions. However they considered only one period and didn't show the role of monsoon in the energy redistribution. Here we go one step further by quantifying the role of monsoon in the system and by investigating if the changes of seasonality between the different periods have an impact on the role of monsoon in the system.

In part 2 we present the experimental design and the insolation characteristics of the different periods. Part 3 considers the large scale climatic changes and the impact on the Indian and African monsoons. The role of monsoon in the energetics of the tropical regions is discussed in part 4 , and part 5 highlights the major conclusions.

\section{Experimental design}

A set of 6 simulations was performed for the Eemian and the Holocene, to account for different orbital configurations across these two interglacial periods (Table 1), using the 
IPSL_CM4 coupled model (Marti et al., 2005). The choice of the periods results from a compromise between a strict analogy in precession between different periods in the Eemian and the Holocene and the expertise developed at LSCE for the last interglacial (126 ka - Joussaume and Braconnot, 1997; Khodri et al., 2003), the last glacial inception (115 ka - de Noblet et al., 1996; Khodri et al., 2001), or the mid Holocene (6 ka - Braconnot et al., 1999; Braconnot et al., 2000). The orbital parameters corresponding to these simulations are listed in Table 1. They were computed following Berger (1978).

\subsection{Model description and experiments}

The simulations were performed with the same version of the IPSL model than the one used for future climate projections (Dufresne et al., 2005; Marti et al., 2005) and for the simulations of the second phase of the Paleoclimate Modelling Intercomparison Project (Braconnot et al., 2007a). IPSL_CM4 couples the grid point atmospheric general circulation model LMDZ (Hourdin et al., 2006) developed at Laboratoire de Météorologie Dynamique (LMD, France) to the oceanic general circulation model (Madec et al., 1998) developed at the Laboratoire d'Océanographie et du Climat (LOCEAN, ex LODYC, France). On the continent, the land surface scheme ORCHIDEE (Krinner et al., 2005) is coupled to the atmospheric model. Only the thermodynamic component of ORCHIDEE is active in the simulations presented here. The closure of the water budget with the ocean is achieved thanks to a river routing scheme implemented in the land surface model. A sea-ice model (Fichefet and Morales Maqueda, 1997), which computes ice thermodynamics and dynamics, is included in the ocean model. The ocean and atmospheric models exchange surface temperature, sea-ice cover, momentum, heat and fresh water fluxes once a day, using the OASIS coupler (Terray et al., 1995) developed at CERFACS (France). None of these fluxes are corrected.

In its present configuration, the model is run at medium resolution. The atmospheric grid is regular, with a resolution of $3.75^{\circ}$ in longitude, $2.5^{\circ}$ in latitude, and 19 levels in the vertical. The ocean model grid has approximately 2 degrees resolution ( 0.5 degrees near the equator) with 182 points in longitude, 149 points in latitude and 31 levels in the ocean.

For all the simulations the model is integrated from an ocean at rest with temperature and salinity prescribed to the Levitus's (1982) climatology. In all simulations the date of the vernal equinox is fixed to March 21 at noon. Trace gases are prescribed to the preindustrial values, so that only the changes in the orbital parameters are accounted for. The initial state for the atmosphere corresponds to a 1st January representative of present day climate. The model is then run long enough, so that the surface and middle ocean are equilibrated with the forcing. The lengths of the simulations range from 300 to 700 years. In some of the shorter simulations the deep ocean still drifts by a small amount. However, this drift doesn't affect the characteristics of the monsoon we analyse here. The analyses are performed considering mean annual cycles that were computed from the last 100 years of each simulation. Note that, for all the simulations, we use the present day calendar to compute the monthly means rather that a "celestial calendar" based on the time spent between equinoxes and solstices that would be more appropriate (see Joussaume and Braconnot, 1997). The leads and lags between the different simulations should thus be interpreted with caution around the autumnal equinox, when the difference between the two calendars is the largest.

\subsection{Insolation for key periods of the Eemian and of the Holocene}

The major differences between the simulations come from the insolation forcing (Table 1). The time periods were chosen to allow similar changes in precession and thus in seasonality across the Eemian and the Holocene. Indeed precession is the key parameter that determines at which time in the year insolation is maximum or minimum, as well as the length of the seasons (see Berger, 1988). Compared to present day, $126 \mathrm{ka}$ and $9.5 \mathrm{ka}$ are two periods for which the equinoxes and solstices are rotated by $180^{\circ}$ along the Earth's orbit. Therefore, for these two periods, the seasonal cycle of insolation is enhanced in the Northern Hemisphere and damped in the Southern Hemisphere (SH). The major changes in insolation occur at the solstices. Following Kepler's laws boreal winter is also longer and boreal summer shorter (Table 1). Here we define these two seasons by the time spent between the equinoxes. Note that $9.5 \mathrm{ka}$ was chosen so as to be consistent with the simulation of the Early Holocene proposed as part of the PMIP working group on the Holocene of PMIP2 (Crucifix et al., 2005).

The mid-Holocene (6 ka) is also a key period of interest for the Palaeoclimate Modeling Intercomparison Project (Joussaume et al., 1999, Braconnot et al., 2007b) for which the seasonal cycle of insolation is also enhanced in the $\mathrm{NH}$ and damp in the SH. In that case, solstices and equinoxes are rotated by about $90^{\circ}$ compared to present day. The maximum changes in insolation with present day do not occur at the solstices but later in the summer season. We added a corresponding period in the Eemian with a simulation of $122 \mathrm{ka}$. The latter was chosen so that the precession is as close as possible to the precession of $6 \mathrm{ka}$ and of the simulation VE11 discussed by Braconnot and Marti (2003) to allow for possible comparisons with earlier studies on the seasonality in the tropical regions.

For the last two periods considered, the precession is similar to present day. The pre-industrial is the reference for the reminder of this study. This simulation is the same as the one used for future climate projections (Dufresne et al., 2005; Swingedouw et al., 2006). In the Eemian we consider for analogy the last glacial inception at $115 \mathrm{ka}$. The differences between $115 \mathrm{ka}$ and the preindustrial are thus mainly due to 

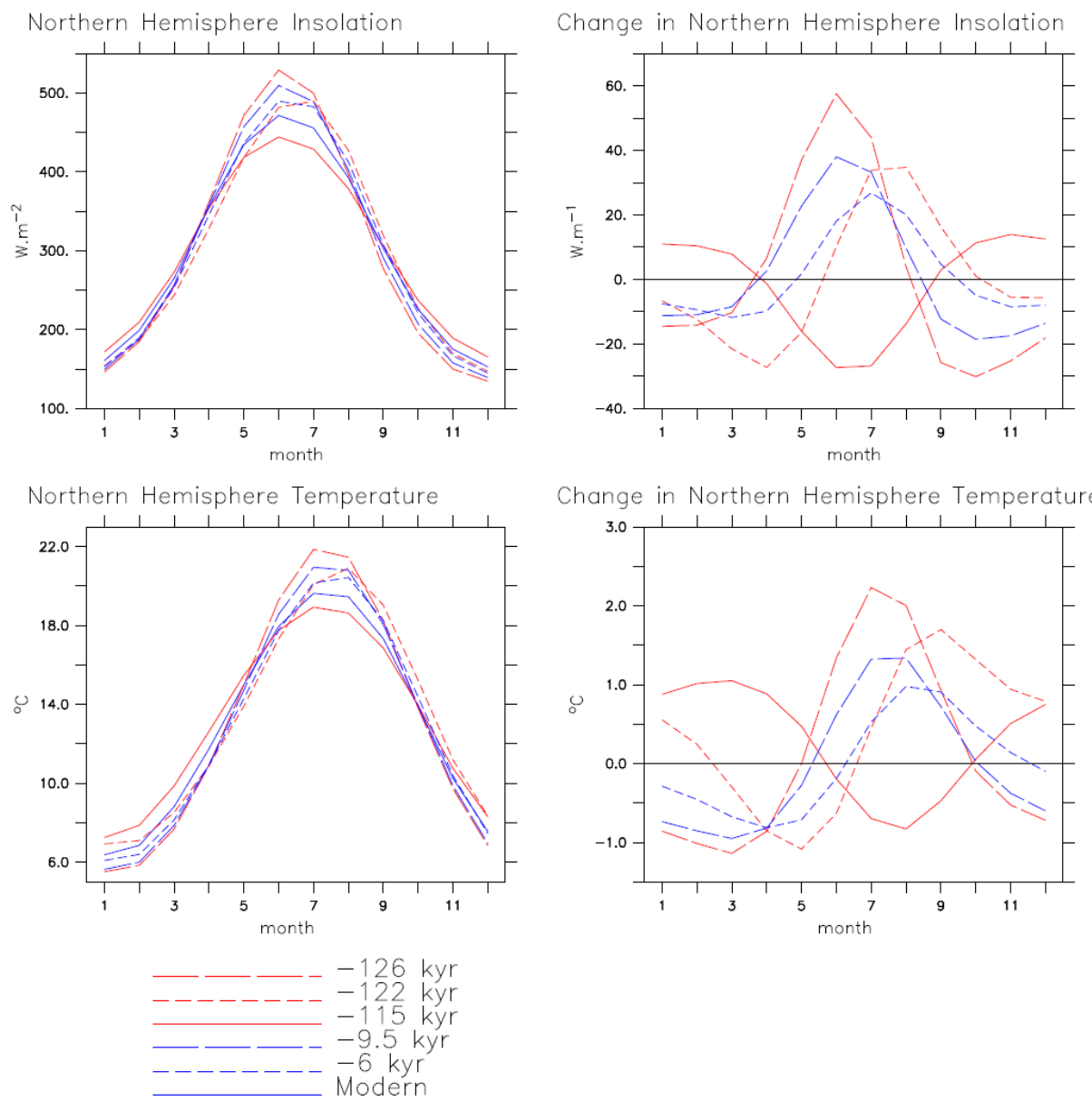

Fig. 2. (a) Insolation $\left(\mathrm{W} / \mathrm{m}^{2}\right)$ and (b) surface air temperature $\left({ }^{\circ} \mathrm{C}\right)$ averaged over the Northern Hemisphere and plotted as a function of months. (c) and (d) same as (a) and (b), but for the differences with $0 \mathrm{ka}$. In all the figures, periods in the last interglacial are represented with red lines and periods in the Holocene with blue lines. Periods with similar precession are represented with lines of the same type.

eccentricity. Indeed, the effect of precession on the insolation forcing is modulated by eccentricity (Berger, 1988). It is larger when eccentricity is larger. The effect of eccentricity also explains why the changes in the length of the seasons are larger for the Eemian than for the Holocene for similar precession parameters (Table 1).

The combination of the different parameters leads to the insolation provided in Fig. 2 for the NH. As expected from the orbital parameters the seasonal cycle of insolation in the Northern Hemisphere increases when the perihelion occurs near the summer solstice and eccentricity is large. Therefore the amplitude of the insolation seasonal cycle is minimum at $115 \mathrm{ka}$, and increases respectively for $0 \mathrm{ka}, 6 \mathrm{ka}$, $122 \mathrm{ka}, 9.5 \mathrm{ka}$ to reach the maximum at $126 \mathrm{ka}$ (Fig. 2). The maximum differences between the simulations occur during boreal summer where it reaches up to $50 \mathrm{~W} / \mathrm{m}^{2}$ for $126 \mathrm{ka}$ (Fig. 2). Figure 2 also clearly shows the different seasonal phasing of the change in insolation. The maximum differences are in phase with the modern insolation for $126 \mathrm{ka}$,
$9.5 \mathrm{ka}$ and $115 \mathrm{ka}$, and are thus maximum in DecemberJanuary and June-July, near the time of the solstices. For $6 \mathrm{ka}$ and $122 \mathrm{ka}$, the differences are shifted in time by about 1 month. The maximum shift is seen for $122 \mathrm{ka}$ (Fig. 2).

Insolation at mid and high latitude is affected by the changes in precession and eccentricity, but the impact of these two parameters is emphasised in these regions when the obliquity is large. The decrease in obliquity across the interglacial is also a common feature between the Eemian and the Holocene. This means that high latitudes received less insolation with time from $126 \mathrm{ka}$ to $115 \mathrm{ka}$ or from $9.5 \mathrm{ka}$ to $0 \mathrm{ka}$ and that the tropical and the equatorial regions received more insolation. However the changes in obliquity are larger $\left(1.5^{\circ}\right)$ and more gradual across the Eemian than across the Holocene $\left(0.8^{\circ}\right)$, for which there is nearly no change between $9.5 \mathrm{ka}$ and $6 \mathrm{ka}$. 


\section{Precipitation in summer JJAS}
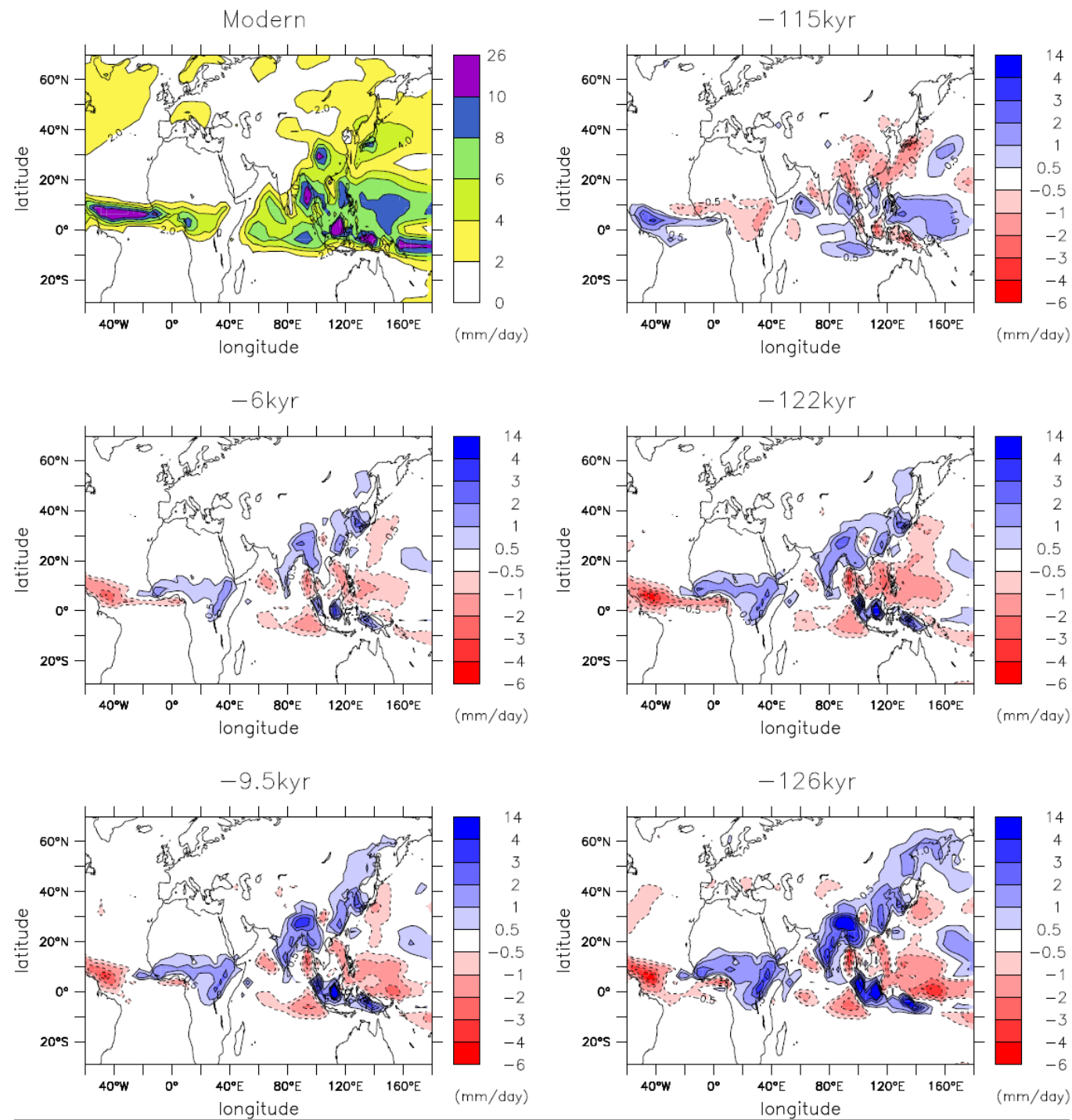

Fig. 3. 0 ka precipitation over Asia $(\mathrm{mm} / \mathrm{d})$ and differences with $0 \mathrm{ka}$ precipitation over Asia $(\mathrm{mm} / \mathrm{d})$ for the different periods analysed here.

\section{Characteristics of the Asian monsoon for the different time periods}

\subsection{Large scale features}

The NH warming increases from $115 \mathrm{ka}, 0 \mathrm{ka}, 6 \mathrm{ka}, 9.5 \mathrm{ka}$, $122 \mathrm{ka}$ to $126 \mathrm{ka}$ (Fig. 2). The response of the surface air temperature follows quite well the insolation forcing with about one month delay. As discussed is several publications, this delay is mostly induced by the response of the ocean (Braconnot et al., 2000; Liu et al., 2003a). The difference reaches about $2^{\circ} \mathrm{C}$ between $126 \mathrm{ka}$ and $0 \mathrm{ka}$ in July-August averaged over the NH (Fig. 2). However, the temperature change over the $\mathrm{NH}$ is not a true linear response to the insolation forcing. As an example, the spring temperature change is relatively more pronounced in all simulations than the summer one. Also the summer warming at $122 \mathrm{ka}$ is larger than at $9.5 \mathrm{ka}$, whereas the $\mathrm{NH}$ insolation has a similar magnitude. These differences come from the latitudinal distribution of the insolation forcing that differs from one period to the other. Therefore, the hemispheric averages mask differences in the insolation for different latitude bands that also controls large scale temperature, pressure gradients, and non-linear hydrological feedbacks.

All the simulations share similar gross features compared to $0 \mathrm{k}$. The warming is larger over land than over the ocean and the pattern resembles the pattern found for $6 \mathrm{ka}$ for the PMIP2 simulations (Braconnot et al., 2007a). This increased warming from $115 \mathrm{ka}, 0 \mathrm{ka}, 6 \mathrm{ka}, 122 \mathrm{ka}, 9.5 \mathrm{ka}$ to $126 \mathrm{ka}$ 

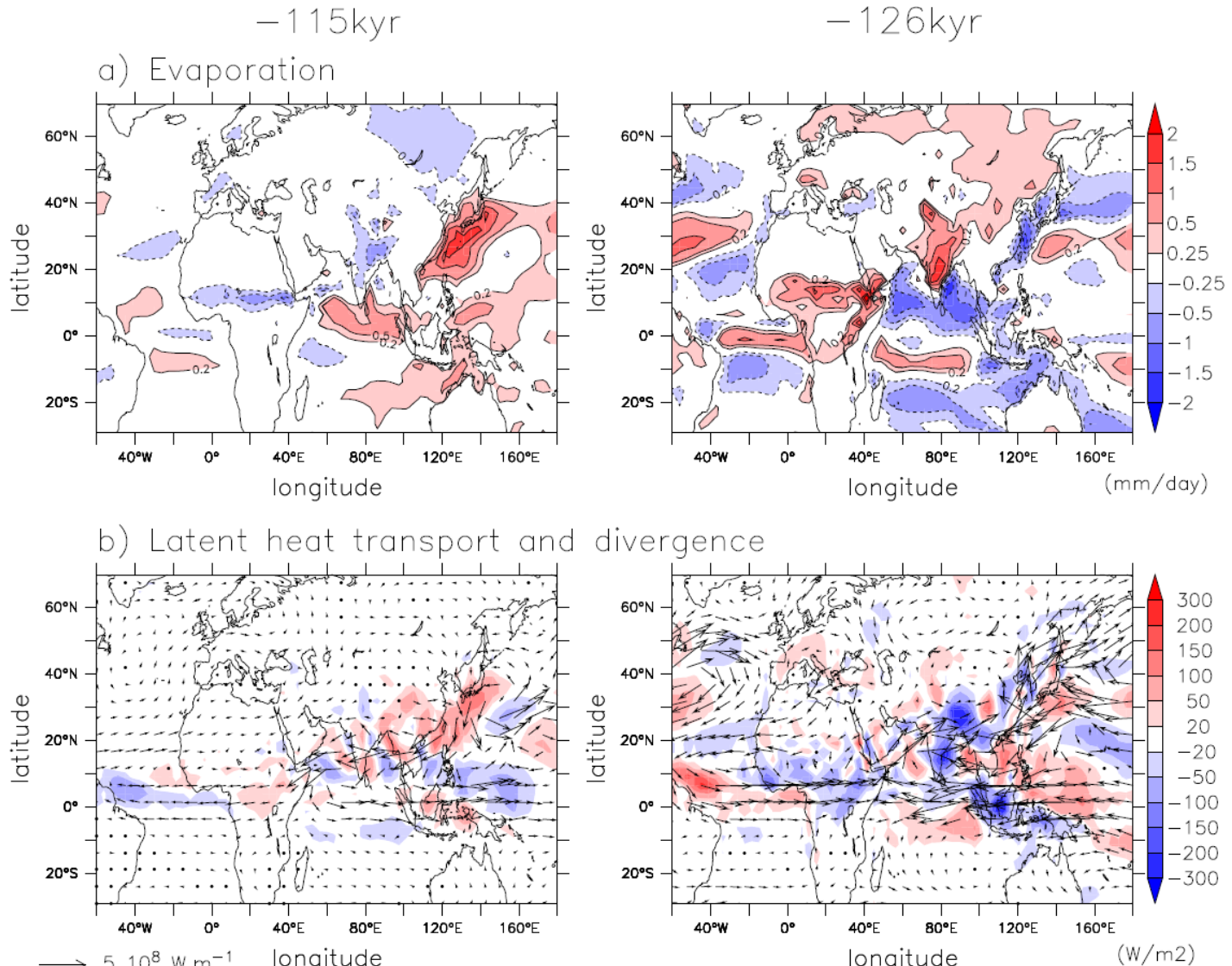

divergence
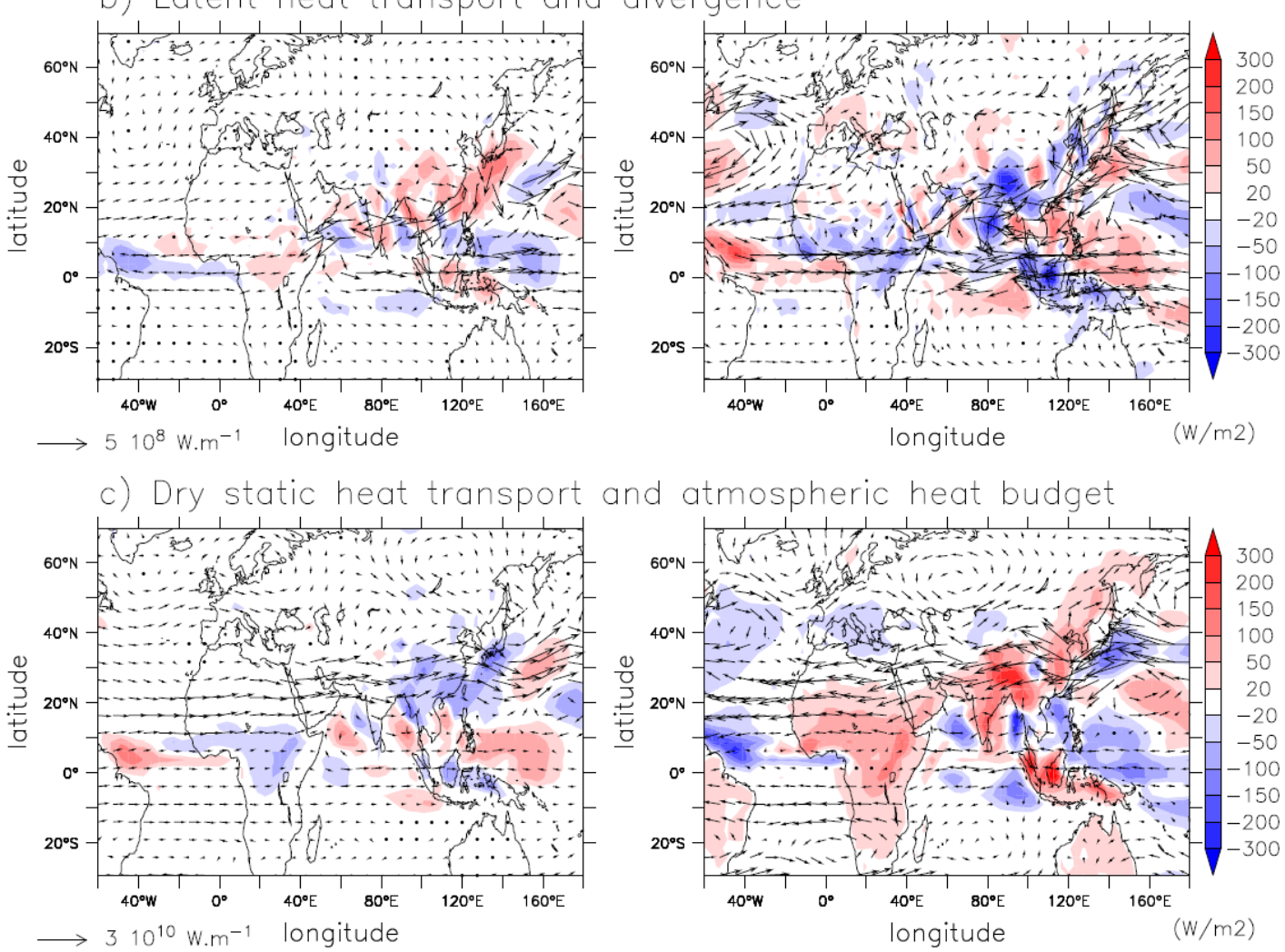

Fig. 4. $126 \mathrm{ka}$ and $115 \mathrm{ka}$ differences with $0 \mathrm{ka}$ for (a) evaporation ( $\mathrm{mm} /$ day), (b) the transport of latent heat integrated over the atmospheric column (arrows, W/m) and its divergence (shading, $\mathrm{W} / \mathrm{m}^{2}$ ) (b) the transport of dry static energy integrated over the atmospheric column (arrows, $\mathrm{W} / \mathrm{m}$ ) and the net heat budget for the dry atmosphere (shading, $\mathrm{W} / \mathrm{m}^{2}$ ).

enhances the interhemispheric temperature contrast in summer as well as the land-sea temperature contrast and contributes to enhance the monsoon flow (Fig. 3).

Compared to the pre-industrial $(0 \mathrm{ka})$ period, precipitations are increased over India, southwest Asia and Africa for $126 \mathrm{ka}, 9.5 \mathrm{ka}, 122 \mathrm{ka}$ and $6 \mathrm{ka}$ following the increased contrast in temperature between land and ocean, and reduced for $115 \mathrm{ka}$ (Fig. 3). The changes in precipitation have opposite sign over the warm pool, the Arabian Sea and the Bay of Bengal. Note that the change in precipitation over land and the meridional shift of the Intertropical Convergence Zone (ITCZ) may be underestimated in our results because monsoon intensity is underestimated in the northern part of the ITCZ in the version of the IPSL model we use (Fig. 3a). 
The change in precipitation over land is a combination of change in the large scale advection of water vapour and local recycling. We illustrate these two terms for $126 \mathrm{ka}$ and $115 \mathrm{ka}$ in Fig. 4. At $126 \mathrm{ka}$, evaporation is reduced over the ocean compared to the control simulation. This results from a combination of a cooler ocean, which imposes a large stability over the ocean and from reduced wind speed. Over land, evaporation increases where precipitation increases in the monsoon regions. However, the increase in the local recycling is not the dominant source of precipitation. The large scale dynamics plays a dominant role. The strengthening of the interhemispheric gradient and the increased land-sea contrast with large increase of tropospheric warming over the Tibetan plateau, favours the advection of moist air from the ocean into the monsoon regions. Figure $4 \mathrm{~b}$ shows the strengthening of the monsoon flow at $126 \mathrm{ka}$, the increased moisture divergence over the ocean and increased moisture convergence over land. Even though evaporation is reduced over the ocean, the change in the atmospheric circulation is such that moisture is depleted over the ocean at the expense of the continent. Regions that most contribute to the water advections over land are the Pacific warm pool, the southern tropical Indian Ocean, and the tropical Atlantic north of the Equator. At $115 \mathrm{ka}$, the situation is reversed and the regions acting as an additional source for $126 \mathrm{ka}$ are convergence zones (Fig. 4). The monsoon flow is reduced and so is the local recycling over land. The local recycling over land is therefore strongly coupled to the intensity of the monsoon, and also results from the changes in large scale circulation. Note that changes extend also to mid latitudes at $126 \mathrm{ka}$, whereas they are more limited to the Tropics at $115 \mathrm{ka}$. This may be due to the low obliquity at $115 \mathrm{ka}$. The other periods present similarities with $126 \mathrm{ka}$, even though the magnitude of the changes is smaller. Also mid-Holocene simulations (9.5 ka and $6 \mathrm{ka}$ ) do not show strong signal in mid-latitudes. The $122 \mathrm{ka}$ also shows large changes in the mid-latitudes in the North Atlantic and the North Pacific (Fig. 3).

\subsection{Changes in seasonality over India and Africa}

Changes in insolation have a large impact on African and Indian monsoon precipitation. Figure 5 shows the precipitation averaged over these two regions for the different simulations compared to pre industrial. In each region the change in precipitation follows well the change in insolation and in temperature averaged over the $\mathrm{NH}$ (Fig. 2). The smaller precipitation is found for $115 \mathrm{ka}$, where the monsoon is damped compared to present, and the maximum precipitation is found for $126 \mathrm{ka}$. It is however interesting to note some differences in the timing of the precipitation change compared to insolation and temperature averaged over the $\mathrm{NH}$.

The precipitation in India is stronger from May to July at $126 \mathrm{ka}$ compared to present. Consistently with the insolation forcing, the maximum change is reach in August at $122 \mathrm{ka}$ and extends to the late summer season (Fig. 5), whereas a) Change in precipitation over India
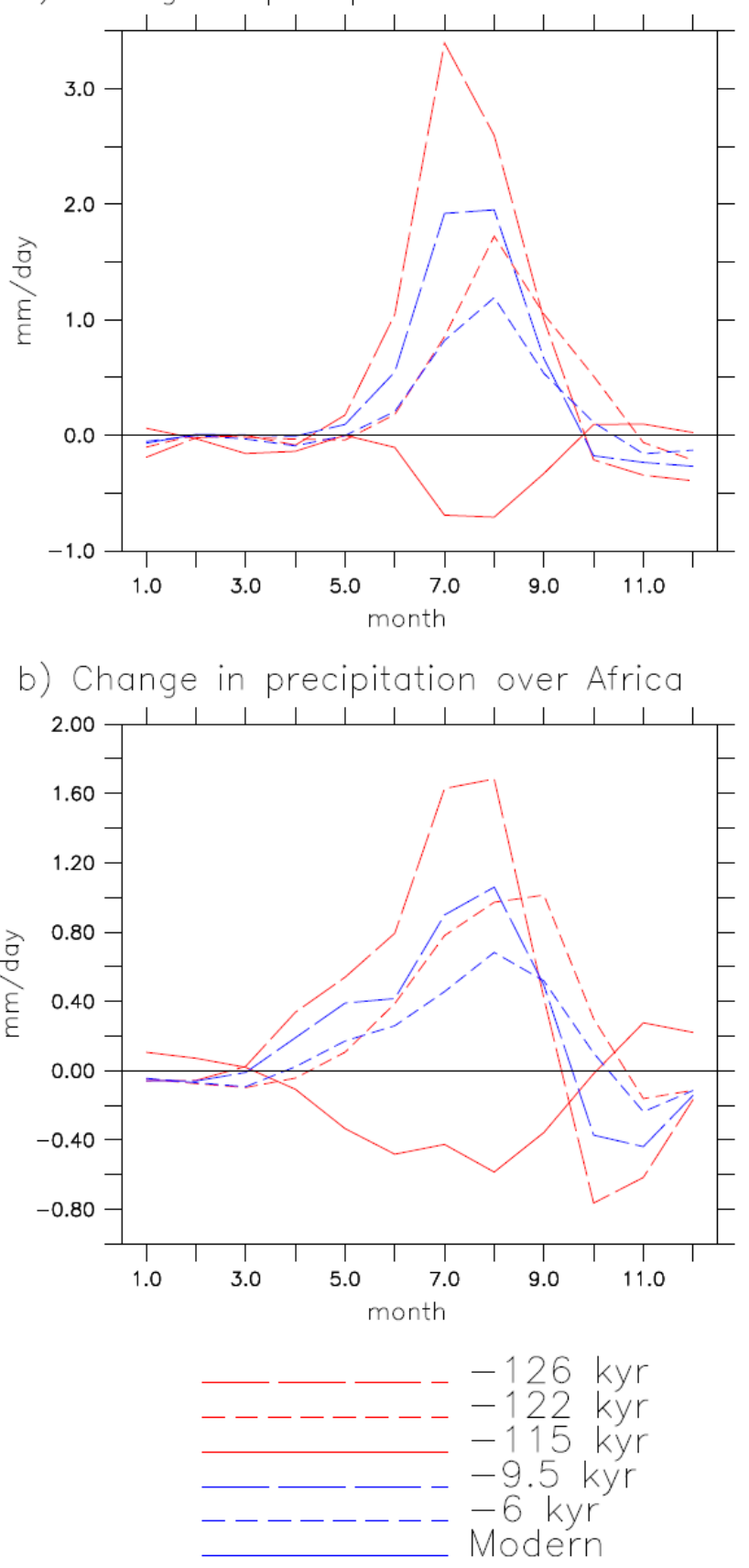

Fig. 5. Precipitation (mm/day) averaged over West Africa $\left(17^{\circ} \mathrm{W}-\right.$ $\left.30^{\circ} \mathrm{E} ; 8^{\circ} \mathrm{N}-18^{\circ} \mathrm{N}\right)$ and north of India $\left(70^{\circ} \mathrm{E}-100^{\circ} \mathrm{E} ; 25^{\circ} \mathrm{N}-\right.$ $40^{\circ} \mathrm{N}$ ) in the northern flank of the ITCZ.

the reduced precipitation simulated for $115 \mathrm{ka}$ varies seasonally in phase with $126 \mathrm{ka}$. The shape of the changes in the seasonal cycle at $9.5 \mathrm{ka}$ has similar shape to the one found for $126 \mathrm{ka}$ due to similar precession. Also since $126 \mathrm{ka}$ and $9.5 \mathrm{ka}$ have similar obliquity the insolation forcing acts similarly as a function of latitude and the major differences in the magnitude of the change are due to the magnitude of the 


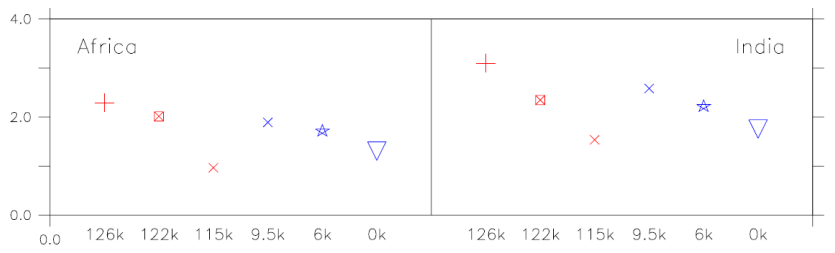

Fig. 6. Mean change of precipitation ( $\mathrm{mm} /$ day) averaged from June to September in North India $\left(70^{\circ} \mathrm{E}-100^{\circ} \mathrm{E} ; 25^{\circ} \mathrm{N}-40^{\circ} \mathrm{N}\right)$ and Africa $\left(17^{\circ} \mathrm{W}-30^{\circ} \mathrm{E} ; 8^{\circ} \mathrm{N}-18^{\circ} \mathrm{N}\right)$ for the different periods considered in this study.

insolation. Similarly, the timing of the change of the seasonal cycle of precipitation at 6 ka shares lots of analogy with $122 \mathrm{ka}$. However, the shape of the insolation forcing suggests that the change in precipitation at $122 \mathrm{ka}$ should lag those of $6 \mathrm{ka}$. The similarity in precipitation between those two periods results from changes in the latitudinal gradient of the insolation forcing and of the temperature response. At $6 \mathrm{ka}$ the maximum change in insolation is located rather north in spring, because of the larger obliquity. At $122 \mathrm{ka}$ the maximum change in spring and early summer insolation is located in mid-latitudes, because of reduced obliquity. Therefore the heating of the Tibetan plateau is equivalent for these two periods and so is the amplification of the Indian monsoon. Then the larger insolation at $122 \mathrm{ka}$ compared to $6 \mathrm{ka}$ drives stronger Indian and African monsoons. It is not possible to discuss the timing of the withdrawal of the monsoon from these figures, since the calendar we use introduces artificial biases in the analyses (see Sect. 2.2).

Figure 5 also suggests that the Indian and the African monsoons have specific regional responses. In particular the relative magnitude of the two monsoon systems seems to depend on the insolation forcing. This is better highlighted in Fig. 6 which presents the average precipitation over the whole monsoon season (JJAS) for these two regions. Interestingly the Indian monsoon intensity decreases gradually across the Eemian and across the Holocene, whereas in Africa the decrease between 126 and $122 \mathrm{k}$ or between $9.5 \mathrm{k}$ and $6 \mathrm{ka}$ is smaller than the decrease between $122 \mathrm{ka}$ and $115 \mathrm{ka}$ or between $6 \mathrm{ka}$ and $0 \mathrm{ka}$. This result is discussed in Marzin and Braconnot (in revison, 2008) for the Holocene. It involves a resonant response of the monsoon to the insolation forcing, which is therefore maximum when the forcing is in phase with the development of the monsoon. Since the Indian monsoon is quite strong in July, the changes are more efficient with the $126 \mathrm{ka}$ and the $9.5 \mathrm{ka}$ insolation. The African monsoon is fully developed in August. Therefore it is more affected when the change in insolation is maximum in August, which is the case at $122 \mathrm{ka}$ and $6 \mathrm{ka}$. The similarities we find between the Eemian and the Holocene in the relative variations of the Indian and African monsoons confirms the relationship between the insolation and the monsoon response, and the strong role of the precession in modulating
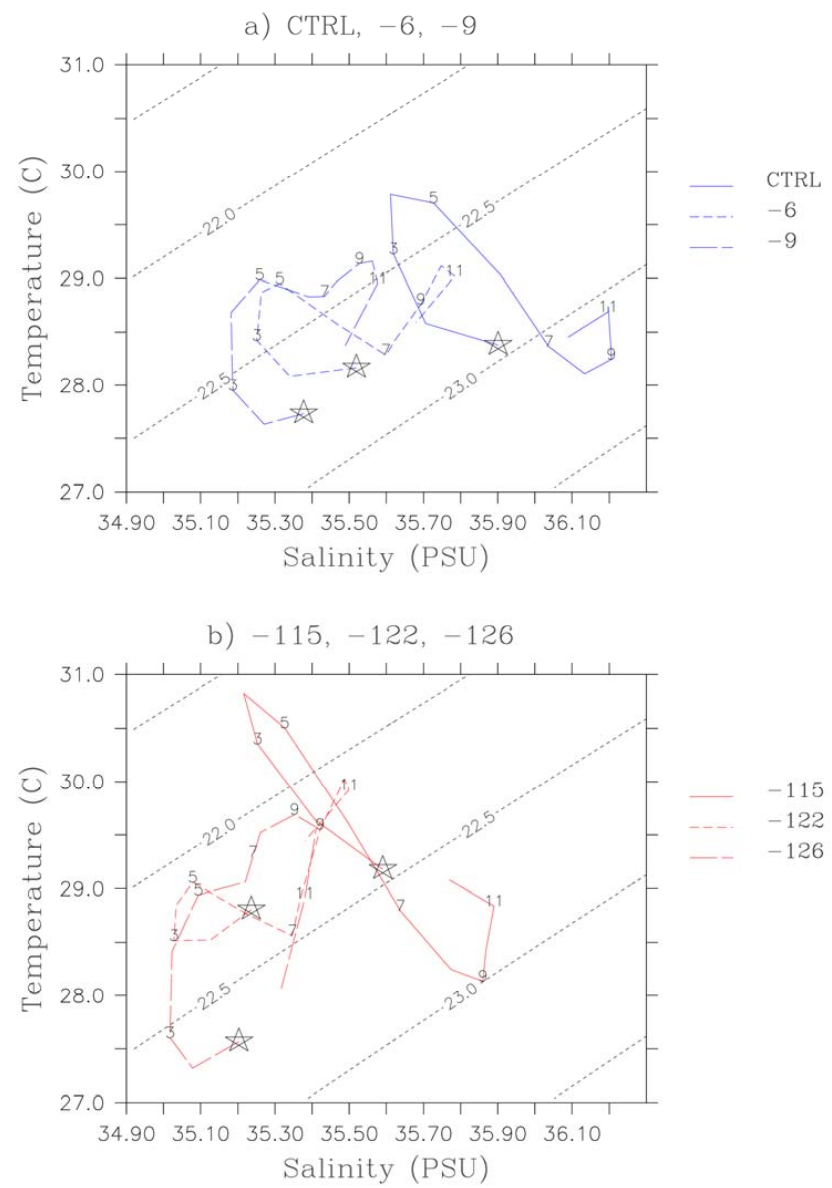

Fig. 7. T/S diagram for a box located between the Equator and the tip of India in the Indian Ocean $\left(65^{\circ} \mathrm{E}-95^{\circ} \mathrm{E} ; 0^{\circ} \mathrm{N}-8^{\circ} \mathrm{N}\right)$ for (a) the Holocene simulations and (b) Eemian simulations. The different points on the curves represent the months and the star stands for January. The dotted lines are the lines of equal density in the T/S diagram.

the timing of the seasonal cycle. The interesting aspect is that the modulation does not have the same impact on different subsystems, and that similarities are found between periods of similar precession.

\subsection{3. Change in seasonality over the Indian Ocean}

Braconnot and Marti (2003) found a strong link between precession, temperature and salinity in the Indian Ocean. Figure 7 presents the surface T/S diagram for a box located between the Equator and the tip of India $\left(65^{\circ} \mathrm{E}-95^{\circ} \mathrm{E} ; 0^{\circ} \mathrm{N}-\right.$ $8^{\circ} \mathrm{N}$ ). The control simulation shares most of the feature we know for present day climate. The SST maximum occurs between the equator and the tip of India in April, prior to the onset of the summer monsoon (Fig. 7) (Rao and Sivakumar, 1999). It corresponds also to the season where the mixed layer depth is quite deep and shoals northward in the Arabian Sea (Rao et al., 1989). Temperature then decreases until 


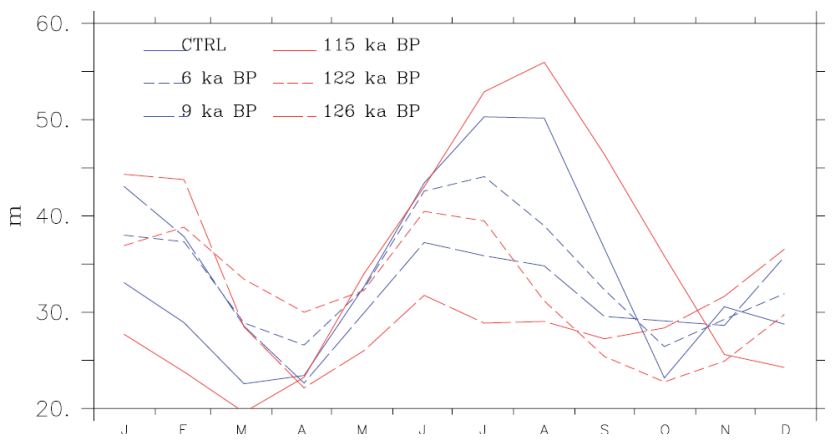

Fig. 8. Annual mean evolution of the mixed layer depth $(\mathrm{m})$ for the different simulations for the same box as in Fig. 7.

Autumn (Fig. 7). In this box salinity is lower during the first half of the year and then increases. The seasonal evolution of salinity is modulated by local precipitation and evaporation and by the advection of fresh water from the Bay of Bengal along the tip of India during winter. In addition, the seasonal evolution of the mixed layer depth is a response to the large scale circulation and to the reversal of the wind between the continent and the ocean. This reversal of wind is associated with the reversal of the monsoon flow that favours upwelling conditions in winter and downwelling conditions during summer (Fig. 8).

During the Holocene, the model produces a reduction of the magnitude of the seasonal cycle of temperature at $9.5 \mathrm{ka}$ and a mean freshening of the surface (Fig. 7). The latter is related to the increase runoff in the Bay of Bengal induced by the strengthening of monsoon rain over the continent, which creates a halocline at the surface (Fig. 3). The SST exhibits warmer than present water throughout summer and a second peak in autumn (Fig. 7a). Similar features are found for $6 \mathrm{ka}$, except that the summer cooling is still present and that a double peak is also created in autumn. The change in surface salinity is slightly smaller, which is consistent with the smaller monsoon amplification relative to the early Holocene. From Fig. 7 we can see that the surface density is smaller during summer. It is associated to a shallower mixed layer depth (Fig. 8). The change of the mixed layer depth reaches approximately $15 \mathrm{~m}$ (about two model vertical levels) at $9.5 \mathrm{ka}$. As discussed in Zhao et al. (2005) and in Braconnot and Marti (2003), it reduces the thermal inertia of the surface ocean, which explains partly the response to the insolation forcing in autumn. Interestingly, compared to $0 \mathrm{ka}$, the shoaling occurs as early as April at $9.5 \mathrm{ka}$, whereas is becomes effective only in July-August at $6 \mathrm{ka}$ (Fig. 8). The difference in the behaviour of the mixed layer depth between the simulations is consistent with the difference in the summer warming between the two simulations. The simulation with the shallower mixed layer depth throughout a longer period responds in phase to the insolation forcing, whereas the other one responds with a delay of one to two months to the insolation forcing (Fig. 7).

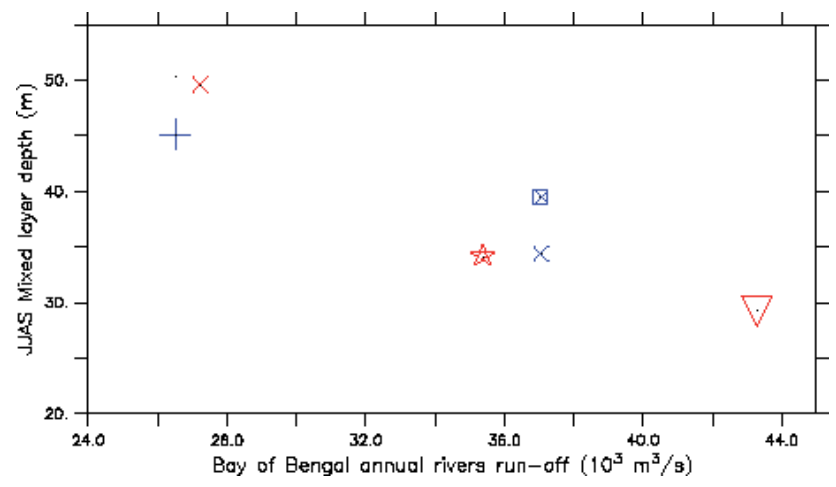

Fig. 9. Relationship between the mixed layer depth in the ocean box located south of the tip of India $\left(65^{\circ} \mathrm{E}-95^{\circ} \mathrm{E} ; 0^{\circ} \mathrm{N}-8^{\circ} \mathrm{N}\right)$ and the annual mean continental runoff in the Bay of Bengal. Each simulation is represented by the same symbol as in Fig. 6 .

The seasonal evolution of SST and salinity across the Eemian shows lots of similarities with the evolution across the Holocene, even though the changes are of larger magnitude (Fig. 7b). In particular, the second peak of SST in autumn is also larger at $126 \mathrm{ka}$ and $122 \mathrm{ka}$, whereas it is not there at $115 \mathrm{ka}$. Also the increased river runoff induces a shift in the mean salinity at $126 \mathrm{ka}$ and $122 \mathrm{ka}$ compared to $115 \mathrm{ka}$. As a result, the thermocline is quite shallow at $126 \mathrm{ka}$ ( $30 \mathrm{~m}$ less than at present day) and responds in phase to the insolation forcing. Figure 9 further assesses the role of the continental runoff in the Bay of Bengal by constraining the surface halocline and therefore the mixed layer depth. Indeed the larger the runoff the shallower the mixed layer is. The remainder of the variations is due to the slight northward shift of the monsoon flow that slightly reduces the Ekman pumping over the tip of India.

This analogy between the changes across the Eemian and the Holocene, for similar orbital configurations, confirms that the timing of the insolation change in spring has a large impact on the development of the mixed layer depth, and that local changes in the mixed layer are coupled to the monsoon activity through local dynamics over the Indian Ocean. The changes in the hydrological cycle and enhanced precipitation over the continent have a remote effect on the ocean mixed layer depth through the river runoff in the Bay of Bengal and the advection of low salinity to the tip of India by the ocean circulation. The difference in the timing of the mixed layer depth and of the surface ocean amongst the simulations is not a simple relationship to the insolation forcing. This certainly needs to be considered when analysing marine proxy that depends on the evolution of the mixed layer depth.

\section{Monsoon and tropical energetics}

Monsoon circulation contributes to redistribute heat and moisture between the hemisphere and across the tropical regions and acts as a major driver of the change in the 

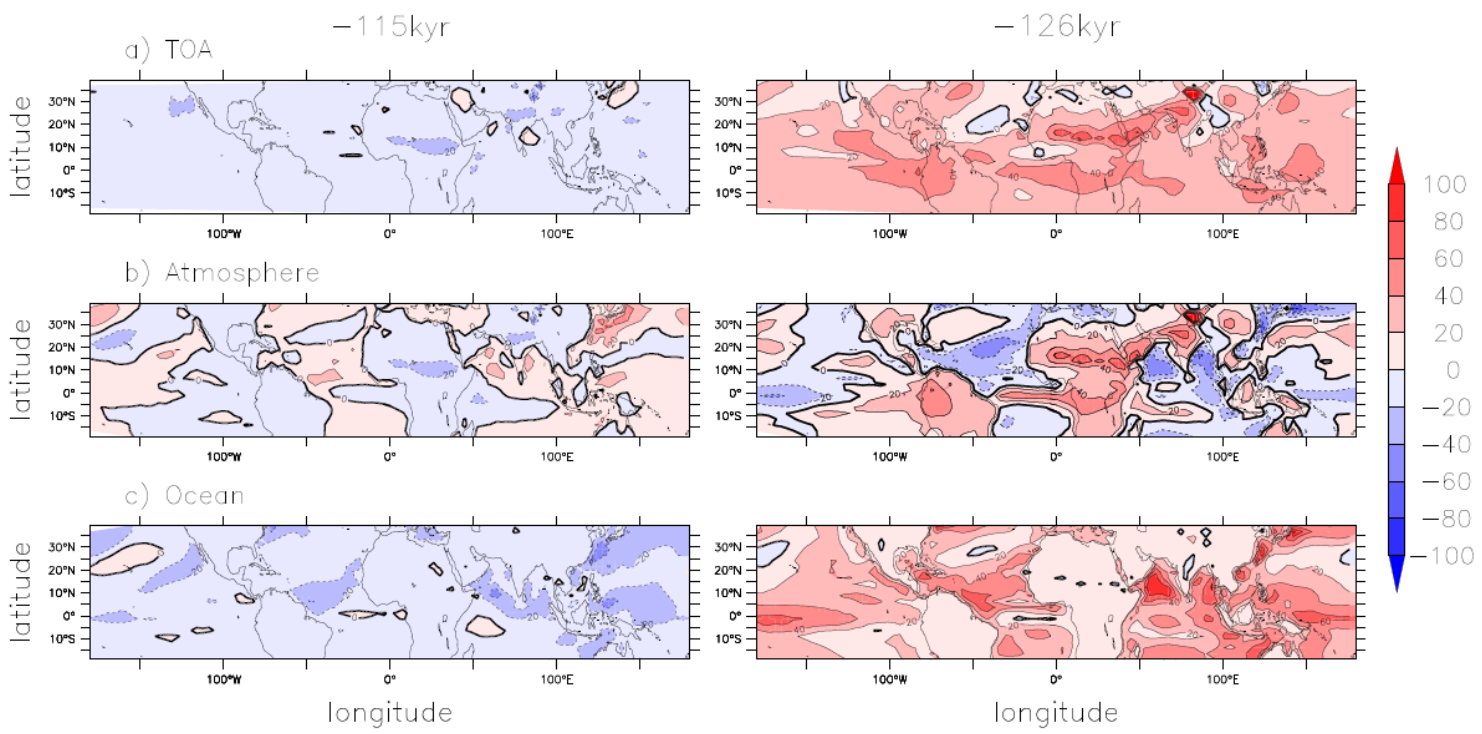

Fig. 10. Characteristics of the change in the ocean-atmosphere heat budget for $115 \mathrm{ka}$ (left and $126 \mathrm{ka}$ (right) and (a) Change in the net heat flux at the top of the atmosphere $\left(\mathrm{W} / \mathrm{m}^{2}\right)$ computed as the budget between shortwave and longwave radiation (positive downward), (b) the change in the total heat budget of the atmosphere $\left(\mathrm{W} / \mathrm{m}^{2}\right)$, considering a humid atmosphere, and (c) the change in the heat fluxes (positive downward) at the ocean surface $\left(\mathrm{W} / \mathrm{m}^{2}\right)$.

atmospheric heat transport and of the large scale circulation between land and ocean. Figure $4 \mathrm{c}$ shows that, in the monsoon region, the atmosphere has excess energy compared to pre-industrial for $126 \mathrm{ka}$ and reduced energy for $115 \mathrm{ka}$ during boreal summer. This excess is then advected to regions where energy is depleted, such as the surrounding tropical oceans (Fig. 4c). It is thus interesting to analyse if the differences found and the seasonal evolution of the African and Indian monsoons have an impact on the contribution of monsoon in the global energetics of the tropical regions.

\subsection{Changes in the tropical heat budget for 115 and $126 \mathrm{ka}$}

The total change in the energetics involves both the response of the ocean and of the atmosphere. Changes in the global energetics of the whole system are well depicted by changes in $\mathrm{radTOA}$, the net heat flux at the top of the atmosphere (Fig. 10a). Changes in radTOA results from changes in the ocean heat gain and in the atmospheric heat budget. The ocean heat budget is provided by the surface heat budget (Qsurf):

Qsurf=radsurf $-\mathrm{Hs}-\mathrm{Hl}$

where radsurf stand for the radiative heat flux (short wave minus long wave) at the surface. The atmospheric heat budget in that case is computed as the difference between the heat budget at the top of the atmosphere and the heat budget at the ocean surface. Therefore evaporation contributes to the budget which implies that we consider a moist atmosphere. This is needed to analyse in a consistent way the global energetics.
For $126 \mathrm{ka}$ and $115 \mathrm{ka}$ the largest changes in $\mathrm{radTOA}$ are found in Africa and in Asia, where monsoon is most affected by the insolation change. Excess energy is also found along the Equator over Africa, the Atlantic Ocean and the East Pacific at $126 \mathrm{ka}$ (Fig. 10a, right). A region of reduced energy also appears for $115 \mathrm{ka}$ in the Atlantic between the Equator and $10^{\circ} \mathrm{N}$, but is not well defined. The comparison of the two periods shows that, except over the Afro-Asian monsoon region, the response of the system is not symmetrical in summer between a period where insolation is in excess and a period where insolation is depleted. Part of the reason comes from a different response of the ocean between the two types of period. Figure 10c shows that the ocean gains more energy at the surface in the Western Pacific at $126 \mathrm{ka}$, whereas nearly no change in the surface heat budget is found for $115 \mathrm{ka}$. Similarly large changes are found south of the equator in the Atlantic and in the Indian ocean at $126 \mathrm{ka}$ that have no counterpart in the $115 \mathrm{ka}$ simulation. On the other hand several regions show a more symmetrical behaviour. This is the case for the Atlantic between 0 and $10^{\circ} \mathrm{N}$, the northern part of the Indian Ocean in the Arabian Sea and the Bay of Bengal, the warm pool and the subtropical high in the West Pacific. All these regions show excess heating at $126 \mathrm{ka}$ and reduced heating at $115 \mathrm{ka}$. They are closely related to a change of opposite sign in the atmospheric heat budget (Fig. 10b). These regions of opposite sign between the ocean and the atmosphere reflects the large scale redistribution of heat between monsoon regions where energy is in excess to ocean regions where ocean seems to pump the energy to the atmosphere. In the East Pacific it is interesting to 


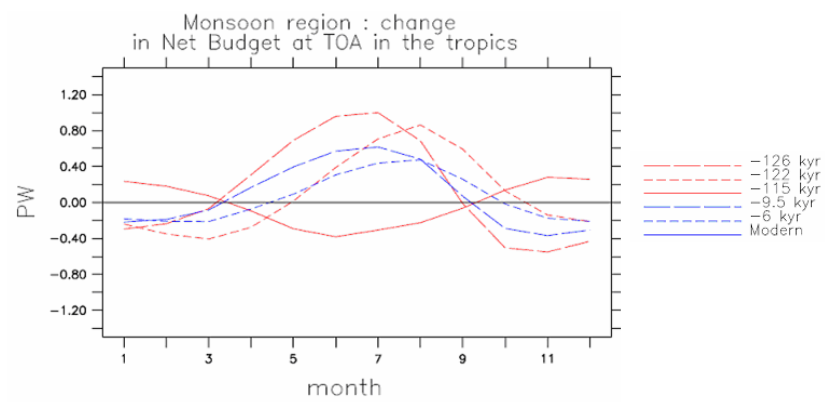

Fig. 11. Change in the top of the atmosphere heat budget (PW) integrated over a box covering the regions affected by the African and the Indian monsoon $\left(17^{\circ} \mathrm{W}-100^{\circ} \mathrm{E} ; 5^{\circ} \mathrm{N}-35^{\circ} \mathrm{N}\right)$ for the different simulations plotted as a function of month.

\section{Amplification of tropical SW forcing in different regions}

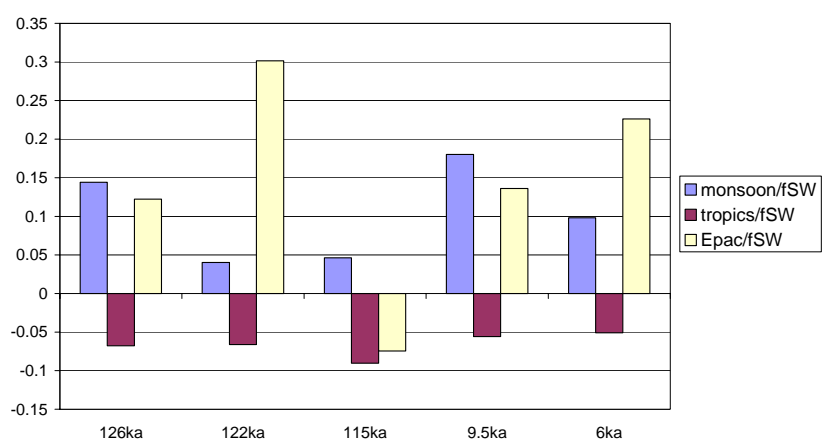

Fig. 12. Amplification of the insolation forcing ( $f S W$; see text for the definition) in different regions of the Tropics and the different simulations. Only the departures to 1 are considered to better highlight the amplification.

note that both the atmosphere and the ocean contribute to the excess energy at the top of the atmosphere at $126 \mathrm{ka}$, and that this region has a non negligible contribution to the change in the tropical energetics.

\subsection{Contribution of monsoon to the tropical heat budget for} the different periods

In order to evaluate the role of monsoon in the global energetics of the tropical regions we integrated the changes found over the continent from $17^{\circ} \mathrm{W}$ to $100^{\circ} \mathrm{E}$ and from the Equator to $35^{\circ} \mathrm{N}$ (Fig. 11). It corresponds to the whole region where the monsoon has a signature at the top of the atmosphere in all the simulations (Fig. 10a). As it is expected from the analysis of monsoon precipitation, the changes over the monsoon region follow the insolation forcing and the changes in precipitation in the African and Indian boxes. It is however difficult from this diagram to tell if the changes only reflect the changes in the insolation or if the monsoon has a larger contribution in some periods compared to others.
In order to better quantify the role of monsoon we compare the mean change in radiative fluxes at TOA averaged over the monsoon season in all the simulation by considering the average value of the positive part of the curves in Fig. 11 for $126 \mathrm{ka}, 122 \mathrm{ka}, 9.5 \mathrm{ka}$, and $6 \mathrm{ka}$, and the negative part of the curve for $115 \mathrm{ka}$. Then we compare the effect of monsoon to similar values obtained for the whole tropics and the east Pacific $\left(130^{\circ} \mathrm{W}-80^{\circ} \mathrm{W} ; 10^{\circ} \mathrm{S}-20^{\circ} \mathrm{S}\right)$ which also has a large signature at TOA (Fig. 12). The comparison in Fig. 12 is done by normalizing each value by the insolation forcing of the period to provide a common metrics independent of the magnitude of the incoming insolation. Following Hewitt and Mitchell (1996), the forcing is the net change in solar radiation at the top of the atmosphere with the assumption that the planetary albedo is that of the control simulation $\left(\alpha_{0}\right)$. Therefore:

$f S W=\left(1-\alpha_{0}\right) \Delta S W_{i}$,

where $\Delta S W_{i}$ represents the change in insolation.

When the whole Tropics are considered the net change in heat fluxes at TOA is smaller than the forcing and represents about $93 \%$ of the forcing whatever the period (Fig. 10). This simply reflects that the different feedbacks, involving changes in shortwave radiation and longwave radiations, damp the insolation forcing. It is however not surprising that the net change at the top of the atmosphere is nearly the insolation forcing since the climate equilibrates to a new state controlled by the change in insolation. Interestingly, this is not the case for the different phenomena (monsoon or mean and variability in the East Pacific). They have a different contribution to this global energetic depending on the period considered (Fig. 12). In all cases the monsoon is a dominant feature of the Tropics and controls part of the response to the insolation forcing. The larger amplification in the monsoon region of $15 \%$ (126 ka) or $18 \%(9.5 \mathrm{ka})$ is found for periods for which the solar forcing is at a maximum at the summer solstice. This figure also shows that, in some periods, the changes are dominated by the East Pacific. The maximum contribution of the Pacific is for periods where the shift in the seasonal changes of insolation relative to the summer solstice is maximum (122 ka and $6 \mathrm{ka})$. This comparison confirms that the new equilibrium of the tropical region is dominated by the insolation forcing, but that depending on the seasonal phasing between the insolation and different climate phenomena, the relative impact of the different regions is different from one climate to the other (Fig. 12). It is however beyond the scope of this paper to analyse the reason of the relative impact of the monsoon and the East Pacific region. 


\section{Conclusions}

We made use of a set of simulations of the Eemian and of the Holocene to analyse the role of the Earth's orbital parameters in shaping the response of the Indian and African monsoon. Our results confirm the strong relationship between increased seasonality of the insolation in the Northern Hemisphere and monsoon amplification. This relationship between monsoon and insolation has been widely discussed in the literature (Prell and Kutzbach, 1987; Liu et al., 2003b) and indicates that the larger the insolation, the larger the monsoon response. To first order it is quasi linear. However we highlight some nonlinear response between the change in insolation averaged over the $\mathrm{NH}$, the temperature response and the precipitation response, which reflects that changes in the latitudinal gradients of insolation and in seasonality have an impact on the response in shaping the latitudinal change in temperature, and trigger or not some of the hydrological feedbacks. The illustration is provided by the intensity of the change in precipitation and in the energetics between the tropical regions and the mid-latitudes.

Our analyses go one step further by considering the relative changes between the Indian and the African monsoon across the Eemian and the Holocene. Our results confirm that the precession has a major contribution to shape the changes in the seasonal cycle, and that the relationship between the seasonal timing of the changes in insolation and the seasonal development of climate phenomena is critical. Indeed we show that it is at the origin of differences between different subsystems, such as the Indian or the African monsoon. It involves resonant interaction between the insolation forcing and the climate response. In particular, increased insolation in the $\mathrm{NH}$ in phase with the summer solstice has a larger impact on the Indian monsoon than on the African monsoon. The African monsoon is more affected when the increased summer insolation occurs in late summer. These resonant responses with the forcing could explain some of the lead and lags between different regions when compared to a particular insolation forcing. They should be considered more carefully when discussing regional changes through time.

This is also the case for the changes in the ocean circulation. We show that when the maximum change in insolation occurs near the summer solstice, the ocean responds nearly in phase with the insolation forcing, whereas when the change in insolation is slightly delayed in summer, the ocean has a larger inertia and respond with a one or two month delay to the insolation forcing. The response of the surface ocean to the insolation forcing has thus implications both on the characteristics of the mixed layer depth and on the timing of its shoaling and deepening. These changes in the seasonal evolution of the mixed layer are linked to the seasonal evolution of precipitation over the continent through the large scale circulation and the river runoff. The reason is that the shallower mixed layer in that case mainly results from the increase fresh water forcing induced by the increased pre- cipitation over land. The shoaling of the mixed layer is still effective when the monsoon retreats from its summer location onto the continent to its winter position over the ocean. The changes in monsoon intensity over land and in the seasonal evolution of the mixed layer do not necessarily cover the same seasons. The change in seasonality of the upper ocean should be considered to analyse multi-proxy records for which each proxy may be representative of a different periods in the seasonal cycle (see Wang et al., 2005). The relative abundance of the different proxies may reflect a different sensitivity to the seasonal cycle. These results reinforced the conclusion of Braconnot and Marti (2003) with an earlier version of the IPSL coupled model. It would be worth complementing this analysis with a simulation of the ocean biology to better infer the role of the change of the mixed layer depth on productivity and on the major characteristics of the ocean ecosystems.

The role of precession in shaping the response of the monsoon and of the coupling between ocean and land also affects the relative role of monsoon in the changes of the energetics of the tropics. Consistent with the dominant role of the summer monsoon in the large scale tropical circulation at the seasonal time scale, the changes in monsoon have a dominant impact on the change in the tropical energetic. We show however that the relative role of monsoon varies from one period to the other, as a function of precession. Again, in our simulations the role of monsoon is dominant when the summer solstice is at the perihelion, which stresses that the role of monsoon is not a simple relationship with insolation forcing in the Tropics. Interestingly the East tropical Pacific also plays a large role when the maximum insolation occurs in late summer. This should be analysed in more depth in future studies. It may reflect large changes in the seasonal evolution of the equatorial upwelling or a signature of the changes of the interannual variability of the El-Nino phenomenon. Several studies indeed show that El-Nino is reduced during the Early and mid-Holocene (Clement et al., 2000), and that this feature is consistent in different simulations (Cane et al., 2006; Zheng et al., 2007). Our results suggest that monsoon and the east Pacific, both contribute to the redistribution of energy and that their relative contribution is controlled by precession. Therefore changes in monsoon do not dominate the changes in the tropical energetics in summer in all the periods. Additional models and model-data comparisons will be needed to fully assess this point and define the role of the changes in the mean position of the ITCZ and clouds compared to changes in climate variability.

Acknowledgements. Computer time was provided by the Centre National de la Recherche Scientifique (IDRIS computing center) and the Commissariat à l'Energie Atomique (CCRT computing center). This work is a contribution to the French ANR blanc " PICC" and ANR Vulnérabilité climat et milieu "Sahelp".

Edited by: A. L. Berger 


\section{References}

Berger, A.: Long-Term Variations of Caloric Solar Radiation Resulting from the Earth's Orbital Elements, Quaternary Res., 9, 139-167, 1978.

Berger, A.: Milankovitch Theory and Climate, Rev. Geophysics, 26, 624-657, 1988.

Braconnot, P., Joussaume, S., Marti, O., and de Noblet, N.: Synergistic Feedbacks from Ocean and Vegetation on the African Monsoon Response to Mid-Holocene Insolation, Geophys. Res. Lett., 26, 2481-2484, 1999.

Braconnot, P., Marti, O., Joussaume, S., and Leclainche, Y.: Ocean Feedback in Response to 6 Kyr BP Insolation, J. Clim., 13, 15371553, 2000.

Braconnot, P. and Marti, O.: Impact of Precession on Monsoon Characteristics from Coupled Ocean Atmosphere Experiments: Changes in Indian Monsoon and Indian Ocean Climatology, Mar. Geol., 201, 23-34, 2003.

Braconnot, P.: Modeling the Last Glacial Maximum and MidHolocene, C. R. Geosci.e, 336, 711-719, 2004.

Braconnot, P., Harrison, S., Joussaume, J., Hewitt, C., Kitoh, A., Kutzbach, J., Liu, Z., Otto-Bleisner, B. L., Syktus, J., and Weber, S. L.: Evaluation of Coupled Ocean-Atmosphere Simulations of the Mid-Holocene, in: Past Climate Variability through Europe and Africa, edited by: Bartabee, R. W., Gasse, F., and Stieckley, C. E., Kluwer Academic publisher, 515-533, 2004.

Braconnot, P., Otto-Bliesner, B., Harrison, S., Joussaume, S., Peterchmitt, J. Y., Abe-Ouchi, A., Crucifix, M., Driesschaert, E., Fichefet, T., Hewitt, C. D., Kageyama, M., Kitoh, A., Laine, A., Loutre, M. F., Marti, O., Merkel, U., Ramstein, G., Valdes, P., Weber, S. L., Yu, Y., and Zhao, Y.: Results of PMIP2 Coupled Simulations of the Mid-Holocene and Last Glacial Maximum Part 1: Experiments and Large-Scale Features, Clim. Past, 3, 261-277, 2007a, http://www.clim-past.net/3/261/2007/.

Braconnot, P., Otto-Bliesner, B., Harrison, S., Joussaume, S., Peterchmitt, J. Y., Abe-Ouchi, A., Crucifix, M., Driesschaert, E., Fichefet, T., Hewitt, C. D., Kageyama, M., Kitoh, A., Loutre, M. F., Marti, O., Merkel, U., Ramstein, G., Valdes, P., Weber, L., Yu, Y., and Zhao, Y.: Results of Pmip2 Coupled Simulations of the Mid-Holocene and Last Glacial Maximum - Part 2: Feedbacks with Emphasis on the Location of the Itcz and Mid- and High Latitudes Heat Budget, Clim. Past, 3, 279-296, 2007b, http://www.clim-past.net/3/279/2007/.

Cane, M. A., Braconnot, P., Clement, A., Gildor, H., Joussaume, S., Kageyama, M., Khodri, M., Paillard, D., Tett, S., and Zorita, E.: Progress in Paleoclimate Modeling, J. Clim., 19, 5031-5057, 2006.

Clement, A. C., Seager, R., and Cane, M. A.: Suppression of El Nino During the Mid-Holocene by Changes in the Earth's Orbit, Paleoceanography, 15, 731-737, 2000.

Crucifix, M., Braconnot, P., and Otto-Bleisner, B. L.: New Targets for the Paleo Modeling Intercomparison Project, EOS, 86, 264$265,2005$.

de Noblet, N., Prentice, I. C., Joussaume, S., Texier, D., Botta, A., and Haxeltine, A.: Possible Role of Atmosphere-Biosphere Interactions in Triggering the Last Glaciation, Geophys. Res. Lett., 23, 3191-3194, 1996.

Dufresne, J., Quaas, J., Boucher, O., Denvil, S., and Fairhead, L.: Contrasts in the Effects on Climate of Anthropogenic Sulfate Aerosols between the 20th and the 21st Century, Geophys. Res.
Lett., 32, 21, L21703, doi:10.1029/2005GLO23619, 2005.

Fichefet, T. and Morales Maqueda, M. A.: Sensitivity of a Global Sea Ice Model to the Treatment of Ice Thermodynamics and Dynamics, J. Geophys. Res., 102(C6), 12 609-12 646, 1997.

Hewitt, C. D. and Mitchell, J. F. B.: GCM Simulations of the Climate of 6 Kyr BP: Mean Changes and Interdecadal Variability, J. Clim., 9, 3505-3529, 1996.

Hourdin, F., Musat, I., Bony, S., Braconnot, P., Codron, F., Dufresne, J. L., Fairhead, L., Filiberti, M. A., Friedlingstein, P., Grandpeix, J. Y., Krinner, G., Levan, P., Li, Z. X., and Lott, F.: The Lmdz4 General Circulation Model: Climate Performance and Sensitivity to Parametrized Physics with Emphasis on Tropical Convection, Clim. Dyn., 27, 787-813, 2006.

Joussaume, S. and Braconnot, P.: Sensitivity of Paleoclimate Simulation Results to Season Definitions, J. Geophys. Res., 102, 1943-1956, 1997.

Joussaume, S., Taylor, K. E., Braconnot, P., Mitchell, J. F. B., Kutzbach, J. E., Harrison, S. P., Prentice, I. C., Broccoli, A. J., Abe-Ouchi, A., Bartlein, P. J., Bonfils, C., Dong, B., Guiot, J., Herterich, K., Hewitt, C. D., Jolly, D., Kim, J. W., Kislov, A., Kitoh, A., Loutre, M. F., Masson, V., McAvaney, B., McFarlane, N., de Noblet, N., Peltier, W. R., Peterschmitt, J. Y., Pollard, D., Rind, D., Royer, J. F., Schlesinger, M. E., Syktus, J., Thompson, S., Valdes, P., Vettoretti, G., Webb, R. S., and Wyputta, U.: Monsoon Changes for 6000 Years Ago: Results of 18 Simulations from the Paleoclimate Modeling Intercomparison Project (PMIP), Geophys. Res. Lett., 26, 859-862, 1999.

Khodri, M., Leclainche, Y., Ramstein, G., Braconnot, P., Marti, O., and Cortijo, E.: Simulating the Amplification of Orbital Forcing by Ocean Feedbacks in the Last Glaciation, Nature, 410, 570 574, 2001.

Khodri, M., Ramstein, G., de Noblet-Ducoudre, N., and Kageyama, M.: Sensitivity of the Northern Extratropics Hydrological Cycle to the Changing Insolation Forcing at 126 and $115 \mathrm{Ky} \mathrm{BP,} \mathrm{Clim.}$ Dyn., 21, 273-287, 2003.

Krinner, G., Viovy, N., de Noblet-Ducoudre, N., Ogee, J., Polcher, J., Friedlingstein, P., Ciais, P., Sitch, S., and Prentice, I. C.: A Dynamic Global Vegetation Model for Studies of the Coupled Atmosphere-Biosphere System, Global Biogeochem. Cy., 19, GB1015, doi:10.1029/2003GB002199, 2005.

Kutzbach, J. E. and Liu, Z.: Response of the African Monsoon to Orbital Forcing and Ocean Feedbacks in the Middle Holocene, Science, 278, 440-443, 1997.

Levitus, S.: Climatological Atlas of the World Ocean, NOAA/ERL GFDL professional paper 13, Princeton, New Jersey, USA, 276 pp., 1982.

Liu, Z., Brady, E. C., and Lynch-Stieglitz: Global Ocean Response to Orbital Foring in the Holocene, Paleoceanography, 18, 1041, $2003 a$.

Liu, Z., Otto-Bliesner, B., Kutzbach, J., Li, L., and Shields, C.: Coupled Climate Simulation of the Evolution of Global Monsoons in the Holocene, J. Clim., 16, 2472-2490, 2003 b.

Liu, Z., Harrison, S. P., Kutzbach, J., and Otto-Bliesner, B.: Global Monsoons in the Mid-Holocene and Oceanic Feedback, Clim. Dyn., 22, 157-182, 2004.

Madec, G., Delecluse, P., Imbart, M., and Levy, C.: Opa 8.1 Ocean General Circulation Model Reference Manual., Note du Pôle de modélisation, Institut Pierre-Simon Laplace, 11, 94 pp., 1998.

Marti, O., Braconnot, P., Bellier, J., Benshila, R., Bony, S., Brock- 
mann, P., Cadule, P., Caubel, A., Denvil, S., Dufresne, J. L., Fairhead, L., Filiberti, M. A., Foujols, M.-A., Fichefet, T., Friedlingstein, P., Goosse, H., Grandpeix, J. Y., Hourdin, F., Krinner, G., Lévy, C., Madec, G., Musat, I., deNoblet, N., Polcher, J., and Talandier, C.: The New IPSL Climate System Model: IPSL-CM4, Note du Pôle de Modélisation, no. 26, ISSN 1288-1619, 2005.

Marzin, C. and Braconnot, P.: Variations of Indian and African monsoons induced by insolation changes at $6 \mathrm{KyrBP}$ and 9.5 Kyr BP, Clim Dynam., in revision, 2008.

Prell, W. L. and Kutzbach, J. E.: Monsoon Variability over the Past 150,000 Years, J. Geophys. Res., 92, 8411-8425, 1987.

Rao, R. R., Molinari, R. L., and Festa, J. F.: Evolution of the Climatological near-Surface Thermal Structure of the Tropical Indian Ocean.1. Description of Mean Monthly Mixed Layer Depth, and Sea Surface Temperature, Surface Current, and Surface Meteorological Fields, J. Geophys. Res., 94, 10 801-10 815, 1989.

Rao, R. R. and Sivakumar, R.: On the Possible Mechanisms of the Evolution of a Mini-Warm Pool During the Pre-Summer Monsoon Season and the Genesis of Onset Vortex in the SouthEastern Arabian Sea, Q. J. R. Meteor. Soc., 125, 787-809, 1999.
Swingedouw, D., Braconnot, P., and Marti, O.: Sensitivity of the Atlantic Meridional Overturning Circulation to the Melting from Northern Glaciers in Climate Change Experiments, Geophys. Res. Lett., 33, LO7711, doi:10.1029/2006GLO25765, 2006.

Terray, L., Sevault, E., Guilyardi, E., and Thual, O.: The Oasis Coupler User Guide Version 2.0, Cerfacs technical report TR/CMGC, 95-46, 1995.

Wang, P. X., Clemens, S., Beaufort, L., Braconnot, P., Ganssen, G., Jian, Z. M., Kershaw, P., and Sarnthein, M.: Evolution and Variability of the Asian Monsoon System: State of the Art and Outstanding Issues, Quat. Sci. Rev., 24, 595-629, 2005.

Zhao, Y., Braconnot, P., Marti, O., Harrison, S. P., Hewitt, C., Kitoh, A., Liu, Z., Mikolajewicz, U., Otto-Bliesner, B., and Weber, S. L.: A Multi-Model Analysis of the Role of the Ocean on the African and Indian Monsoon During the Mid-Holocene, Clim. Dyn., 25, 777-800, 2005.

Zheng, W., Braconnot, P., Guilyardi, E., Merkel, U., and Yu, Y.: Enso at $6 \mathrm{ka}$ and $21 \mathrm{ka}$ from Ocean-Atmosphere Coupled Model Simulations, Clim. Dyn., 30, 7-8, 745-762, doi:10.1997/s00382007-0320-3, 2007. 